\title{
Measurement of $\mathrm{GABA}_{\mathrm{A}}$ receptor function in rat cultured cerebellar granule cells by the Cytosensor microphysiometer
}

\author{
Maria J. Brown, *Martyn D. Wood, *Martyn C. Coldwell \& ${ }^{1}$ David R. Bristow
}

Division of Neuroscience, School of Biological Sciences, University of Manchester, 1.124 Stopford Building, Oxford Road, Manchester M13 9PT and *SmithKline Beecham Pharmaceuticals, Psychiatry Research, Third Avenue, Harlow, Essex CM19 5AW

$1 \gamma$-Aminobutyric acid (GABA), acting via the GABA $_{A}$ receptor, increased the extracellular acidification rate of rat primary cultured cerebellar granule cells, measured by the Cytosensor microphysiometer.

2 The optimal conditions for the measurement of $\mathrm{GABA}_{\mathrm{A}}$ receptor function in cerebellar granule cells by microphysiometry were: cells seeded at $9-12 \times 10^{5}$ cells/transwell cup and maintained in vitro for 8 days, GABA stimulation performed at $25^{\circ} \mathrm{C}$, with a stimulation time of $33 \mathrm{~s}$.

3 GABA stimulated a concentration-dependent increase in the extracellular acidification rate with an $\mathrm{EC}_{50}$ of $2.0 \pm 0.2 \mu \mathrm{M}$ (mean \pm s.e.mean, $n=7$ experiments) and maximal increase $\left(\mathrm{E}_{\max }\right)$ over basal response of $15.4 \pm 1.2 \%$.

4 The sub-maximal GABA-stimulated increase in acidification rate could be potentiated by the 1,4benzodiazepine, flunitrazepam $(100 \mathrm{nM})$. The $10 \mathrm{nM}$ GABA response showed the maximal benzodiazepine facilitation (GABA alone, $1.4 \mu \mathrm{V} \mathrm{s}^{-1}$, GABA + flunitrazepam, $3.8 \mu \mathrm{V} \mathrm{s}^{-1}$, mean increment over basal, $n=7$ ).

5 The GABA-stimulated increase in acidification rate was inhibited by the $\mathrm{GABA}_{\mathrm{A}}$ antagonist, bicuculline $(100 \mu \mathrm{M})(90 \%$ inhibition at $1 \mathrm{mM}$ GABA).

6 The results of this study show that activation of $\mathrm{GABA}_{\mathrm{A}}$ receptors in rat cerebellar granule cells caused an increase in the extracellular acidification rate; an effect which was potentiated by benzodiazepines and inhibited by a $\mathrm{GABA}_{\mathrm{A}}$ receptor antagonist. This paper defines the conditions and confirms the feasibility of using microphysiometry to investigate $\mathrm{GABA}_{\mathrm{A}}$ receptor function in primary cultured CNS neurones. The microphysiometer provides a rapid and sensitive technique to investigate the regulation of the $\mathrm{GABA}_{\mathrm{A}}$ receptor in populations of neurones.

Keywords: Benzodiazepine; GABA $\mathrm{A}$ receptors; microphysiometer; GABA receptor function; cerebellar granule cells; flunitrazepam

\section{Introduction}

The Cytosensor microphysiometer is a novel tool that has recently become available to measure the extracellular acidification rates in populations of living cells by detecting the extrusion rate of acidic metabolic products (Parce et al., 1989; McConnell et al., 1993). Living cells are confined to a flow chamber and media is pumped over the cells to maintain homeostasis. Flow of media is interrupted for a period of time and, as the media surrounding the cells becomes more acidic due to cellular production of metabolic products, a measurement of acidification rate is obtained (Parce et al., 1989). A variety of ligand-receptor interactions have been demonstrated to produce changes in cellular catabolism which can be measured by microphysiometry (Parce et al., 1989; McConnell et al., 1992). The microphysiometer has been successfully used to examine the stimulation of a number of G-protein-linked receptors (Owicki et al., 1990; McConnell et al., 1992), tyrosine kinase-linked receptors (Rice et al., 1991; Owicki et al., 1990; Nag et al., 1992), and ligand-gated ion channel receptors (Cao et al., 1991; Raley-Susman et al., 1992). In most cases, functional ligand-receptor interactions of both excitatory and inhibitory transmitters result in an increase in cellular acidification rate, implying an increased metabolic rate (McConnell et al., 1992), or activation of $\mathrm{H}^{+}$transporters, for example, the $\mathrm{Na}^{+} / \mathrm{H}^{+}$antiporter (Wada et al., 1993; Nag et al., 1995).

The $\gamma$-aminobutyric $\operatorname{acid}_{\mathrm{A}}\left(\mathrm{GABA}_{\mathrm{A}}\right)$ receptor is a member of the ligand-gated ion channel superfamily, which mediates

\footnotetext{
${ }^{1}$ Author for correspondence.
}

the inhibitory postsynaptic action of GABA. The $\mathrm{GABA}_{\mathrm{A}}$ receptor is a heteroligomeric protein, probably comprising five subunits (Nayeem et al., 1994), which upon agonist activation opens an integral ion channel and allows the passage of chloride ions (Bormann et al., 1987). The $\mathrm{GABA}_{\mathrm{A}}$ receptor is also the site of action of many psychoactive drugs, including 1,4-benzodiazepines, barbiturates, steroids and alcohols (Macdonald \& Olsen, 1994), which modulate the function of the $\mathrm{GABA}_{\mathrm{A}}$ receptor. The techniques currently available for the direct study of $\mathrm{GABA}_{\mathrm{A}}$ receptor function are electrophysiology and ${ }^{36}$ chloride flux, with additional biochemical correlates of receptor functionality including the 'GABA shift' and other allosteric modulation of the binding sites located on the $\mathrm{GABA}_{\mathrm{A}} /$ benzodiazepine receptor complex (Sieghart, 1995). Whilst the ${ }^{36}$ chloride flux studies have undoubtedly provided important information on the $\mathrm{GABA}_{\mathrm{A}}$ receptor (Thampy \& Barnes, 1984; Lehoullier \& Ticku, 1987; Marley \& Gallager, 1989; Miller et al., 1988; Hu \& Ticku, 1994), it is a notoriously difficult procedure with low sensitivity and is not universally applicable to all neuronal cell types, particularly small neurones such as the cerebellar granule cells. The microphysiometer appears to provide a rapid alternative to ${ }^{36}$ chloride flux to study the function of the $\mathrm{GABA}_{\mathrm{A}}$ receptor in populations of neurones.

The application of microphysiometry to primary cultured neurones is not fully established, since most work to date has been performed on transfected cell lines (McConnell et al., 1992). A number of studies have examined neuronal cells, including foetal rat hippocampal cells (Raley-Susman et al., 1990; 1992; Wada et al., 1992), foetal rat hippocampal glial cells (Raley-Susman et al., 1992) and foetal rat astrocytes (Cao 
et al., 1991). The system has recently been updated and significantly modified since these studies, such that cells are now grown directly on the membrane of the transwell cup instead of on glass coverslips (Salon \& Owicki, 1995).

The use of microphysiometry for studying $\mathrm{GABA}_{\mathrm{A}}$ receptor activity in primary cultured neurones has not previously been demonstrated. In this study we have optimized the application of microphysiometry to measure reproducible $\mathrm{GABA}_{\mathrm{A}}$ receptor-mediated responses in primary cultures of rat cerebellar granule cells and showed that the system can detect benzodiazepine modulation of $\mathrm{GABA}_{\mathrm{A}}$ receptor function.

\section{Methods}

\section{Preparation of rat cerebellar granule cells}

Primary cerebellar granule cell (CGC) cultures were prepared from 8 day post-natal day Sprague-Dawley rats as detailed previously (Brown \& Bristow, 1996), except with the modification of using Dulbecco's modified Eagle Medium (DMEM; with $2 \mathrm{mM}$ glutamine, $4.5 \mathrm{~g}^{-1} \mathrm{D}$-glucose, without sodium pyruvate). Briefly, cells were isolated by trypsinization $\left(0.25 \% \mathrm{w} / \mathrm{v}, 15 \mathrm{~min}, 37^{\circ} \mathrm{C}\right)$, followed by trituration in a DNase solution $\left(0.004 \%(\mathrm{w} / \mathrm{v}), 10 \mathrm{~min}, 37^{\circ} \mathrm{C}\right)$ containing a soybean trypsin inhibitor $(0.003 \%(\mathrm{w} / \mathrm{v}))$. Dissociated cells were separated from undigested material by centrifugation (123 $\mathrm{g}$ ) and resuspended in DMEM, supplemented with $10 \%(\mathrm{v} / \mathrm{v})$ foetal bovine serum (heat-inactivated), $50 \mu \mathrm{g} \mathrm{ml} \mathrm{m}^{-1}$ gentamicin, $100 \mathrm{iu}$ penicillin, $100 \mu \mathrm{g} \mathrm{ml}^{-1}$ streptomycin and $25 \mathrm{~mm}$ potassium chloride (supplemented DMEM). CGCs were seeded at a variety of densities between 3 and $16 \times 10^{5}$ cells per $12 \mathrm{~mm}$ Transwell cup (coated with poly-D-lysine at $2 \mu \mathrm{g} \mathrm{cm}^{-2}$ ), and maintained at $37^{\circ} \mathrm{C}$ in a humidified incubator $(95 \%$ air $/ 5 \%$ $\left.\mathrm{CO}_{2}(\mathrm{v} / \mathrm{v})\right)$. The cell suspension in each case was diluted in supplemented DMEM (as above) to create the required cell number $\mathrm{ml}^{-1}$ and $1 \mathrm{ml}$ was pipetted directly onto the transwell cup membrane. Supplemented DMEM (1 ml) was then applied to the surrounding well. Growth media were removed and replaced 18-24 h later with fresh supplemented DMEM containing $10 \mu \mathrm{M}$ cytosine arabinoside, to prevent the division of non-neuronal cells. Cells were maintained in culture $(95 \%$ air $\left./ 5 \% \mathrm{CO}_{2}(\mathrm{v} / \mathrm{v})\right)$ for a further 7 days in vitro (DIV) before experimental treatment.

\section{Optimization of the microphysiometer technique to measure $G A B A_{A}$ receptor-mediated responses}

CGCs were seeded at densities of 3, 6, 9, 12 and $16 \times 10^{5}$ cells/ transwell cup and maintained until 8 DIV (as above) and then placed in the microphysiometer chamber and examined for responses to $100 \mu \mathrm{M}$ GABA. Experiments were also performed on CGC seeded at $9 \times 10^{5}$ cells/transwell cup and maintained for 7.5 days before being placed in either supplemented DMEM (without foetal calf serum) or supplemented DMEM (as above, control) for $12 \mathrm{~h}$, before the response to GABA $(100 \mu \mathrm{M})$ was tested. CGC seeded at $9 \times 10^{5}$ cells/transwell cup and maintained for 8 DIV were examined for their basal and GABA $(100 \mu \mathrm{M})$-stimulated acidification rate at either $37^{\circ} \mathrm{C}$ or $25^{\circ} \mathrm{C}$, and in another series of experiments, the cells were exposed to $\mathrm{GABA}(100 \mu \mathrm{M})$ for either $33 \mathrm{~s}$ or $6 \mathrm{~min}\left(25^{\circ} \mathrm{C}\right)$.

\section{Measurement of cerebellar granule cell extracellular acidification rate with the microphysiometer}

CGC at the required cell density (between 3 and $16 \times 10^{5}$ cells/ transwell cup) were loaded into the microphysiometer chambers and $1 \mathrm{~h}$ was allowed for the cells to stabilize. During this time, the cells reach the required experimental temperature $\left(37^{\circ} \mathrm{C}\right.$ or $25^{\circ} \mathrm{C}$ depending on the individual experiment) and running medium (DMEM without serum and bicarbonate, with $44 \mathrm{mM} \mathrm{NaCl}$, with $2 \mathrm{mM}$ glutamine, with $25 \mathrm{mM} \mathrm{KCl}$ ) was perfused over the cells at $100 \mu \mathrm{lmin}^{-1}$. Running medium was pumped (total pump cycle $1.5 \mathrm{~min}$ ) between the cells and sensor and for the measurement of extracellular acidification rate the flow was halted for a short time $(30 \mathrm{~s})$. During the interruption of medium flow, the cells acidify the medium. Once flow is started again, the $\mathrm{pH}$ in the chamber rises returning to baseline values. The rate of chamber acidification during interrupted medium flow is determined as the slope of a linear least-squares fit to the $\mathrm{pH}$-time data (Owicki et al., 1990). Previous studies have shown this to be an appropriate indicator of cellular metabolic rate (Parce et al., 1989). Measurements of acidification rate were determined and expressed as a mean rate in $\mu \mathrm{V} \mathrm{s}^{-1}$. During the initial experiments a number of pump cycles (involving the pumping of media over the cells for a set period of time before interruption of flow, when the media bathing the cells was measured for acidity) were examined to achieve the best homeostasis for the cells (such that the raw data reached a stable plateau following the measurement phase). A total pump cycle time of $1.5 \mathrm{~min}$ with pump on being $1 \mathrm{~min}$ and the measurements taken during the pump off period between $1 \mathrm{~min} 5 \mathrm{~s}$ to $1 \mathrm{~min} 28 \mathrm{~s}(23 \mathrm{~s})$ being found as the most suitable for examining GABA-mediated responses. In the majority of experiments GABA was applied $50 \mathrm{~s}$ into the pump cycle, taking $7 \mathrm{~s}$ to reach the cells, and thus the response was measured between 3 and $31 \mathrm{~s}$ of GABA stimulation, before the pump was switched on to washout the chamber. With this protocol the GABA stimulation time was $33 \mathrm{~s}$. In a number of the initial experiments, a 6 min GABA stimulation time was used. In these experiments GABA was applied at the beginning of the $1.5 \mathrm{~min}$ pump cycle and was present for four consecutive cycles before being washed off.

\section{Assessment of GABA-mediated responses}

Following optimization of the GABA-mediated response, cells at 8 DIV were examined for their responses to GABA. At 8 DIV, the cells were exposed to $10 \mu \mathrm{M}$ GABA to test the responsiveness of the CGC to GABA. The traces were normalized for this effect so responses were expressed as \% change from basal acidification rate response. Following a $15 \mathrm{~min}$ washout with running medium, a series of GABA concentrations, $10 \mathrm{nM}, 100 \mathrm{nM}, 500 \mathrm{nM}, 1 \mu \mathrm{M}, 10 \mu \mathrm{M}, 100 \mu \mathrm{M}$ and $1 \mathrm{mM}$ (final concentrations), were applied to the cells (exposure time $33 \mathrm{~s}$ followed by a $15 \mathrm{~min}$ washout with running medium before the next concentration). These experiments provided a concentration-response trace for each chamber of cells. Following the GABA dose-response, a $30 \mathrm{~min}$ washout with running medium was performed, followed by a $30 \mathrm{~min}$ exposure to flunitrazepam $(100 \mathrm{nM})$ or bicuculline $(100 \mu \mathrm{M})$. A GABA concentration-response curve $(10 \mathrm{nM}-1 \mathrm{mM})$ in the presence of flunitrazepam $(100 \mathrm{nM})$ or bicuculline $(100 \mu \mathrm{M})$ was then performed as described earlier, with control cells exposed to the GABA concentrations to ensure time-dependent factors were not affecting the responses. In another series of experiments the effect of flunitrazepam $(100 \mathrm{nM})$ alone and bicuculline $(100 \mu \mathrm{M})$ alone were compared to vehicle treated $(0.1 \%(\mathrm{v} / \mathrm{v})$ ethanol) cells. The usual duration of the experiments was 5 to $7 \mathrm{~h}$.

\section{Analysis of data}

Acidification rate responses for each GABA dose and each treatment were performed in duplicate and are expressed as mean acidification rate in $\mu \mathrm{V} \mathrm{s}^{-1} \pm$ s.e.mean rate from representative traces (Figures 2 and 3) or at least 7 independent experiments (Figure 1). Due to a slight variability of basal acidification rates between populations of cells, responses were expressed as mean \pm s.e.mean \% change from basal acidification rate from at least 7 independent experiments for Figures 4 and 5. From each chamber containing a population of cells, an $\mathrm{EC}_{50}$ and maximal response $\left(\mathrm{E}_{\max }\right)$ for GABA was determined for each experiment (GABA alone, or GABA response in the presence of flunitrazepam) by fitting a nonlinear regression best-fit line to the data points by use of the sigmoidal con- 
centration-response (variable slope) equation and GraphPad Prism software. The equation was as follows:

$$
\mathrm{Y}=\min +\left((\max -\min ) / 1+10^{\left(\log \mathrm{EC}_{50}-\mathrm{X}\right) \cdot \mathrm{n}_{\mathrm{H}}}\right)
$$

where, $\mathrm{X}$ is the logarithm of concentration, $\mathrm{Y}$ is the response, min is the minimum response and max is the maximum response, $\mathrm{n}_{\mathrm{H}}$ is the Hill slope. Statistical significance was tested by the Wilcoxon Rank test.

\section{Results}

The effect of cell density on basal and GABA-mediated acidification responses

For experiments run at $37^{\circ} \mathrm{C}$, it was observed that at less than $6 \times 10^{5}$ cells seeded/transwell cup the CGC had a very low basal acidification rate $\left(30 \pm 10 \mu \mathrm{V} \mathrm{s}^{-1}\right.$, mean \pm s.e.mean, $\left.n=3\right)$ and responses to GABA $(100 \mu \mathrm{M})$ could not be detected. The response to GABA at these low cell densities was presumably outside the sensitivity of the instrument. Between 6 and $9 \times 10^{5}$ cells/transwell cup, the cells had a higher basal acidification rate $\left(73 \pm 4 \mu \mathrm{V} \mathrm{s}^{-1}\right.$, mean \pm s.e.mean, $\left.n=7\right)$ and responded to a small extent to GABA stimulation $(100 \mu \mathrm{M}-1 \mathrm{mM}$, $6.5 \pm 1.2 \mu \mathrm{V} \mathrm{s}^{-1}$, mean \pm s.e.mean, $\left.n=7\right)$. Between 9 and $12 \times 10^{5}$ cells, the cells had a basal acidification rate similar to that of cells seeded at $6-9 \times 10^{5}$ cells/cup and responded maximally to $100 \mu \mathrm{M}$ GABA $\left(6.0 \pm 1.0 \mu \mathrm{V} \mathrm{s} \mathrm{s}^{-1}\right.$, mean \pm s.e.mean, $n=3)$. The further increase of cells to $16 \times 10^{5}$ cells transwell cup had no effect on the basal acidification rate or the GABA response (data not shown). In subsequent experiments, cells were seeded at between 9 and $12 \times 10^{5}$ cells/transwell cup.

\section{The effect of incubation temperature on basal acidification rate and maximal GABA-mediated responses}

Figure 1 shows the GABA-mediated responses in $\mathrm{CGC}$ at $25^{\circ} \mathrm{C}$ versus $37^{\circ} \mathrm{C}$. The response to GABA $(100 \mu \mathrm{M})$ in cells at $25^{\circ} \mathrm{C}$ of $9.0 \pm 1.2 \mu \mathrm{V} \mathrm{s}^{-1}$ (mean \pm s.e.mean, $n=7$ ) is significantly greater $(P<0.05$, Wilcoxon Rank test $)$ than responses in cells at $37^{\circ} \mathrm{C}$ of $6.0 \pm 1.0 \mu \mathrm{V} \mathrm{s}^{-1}$ (mean \pm s.e.mean, $n=7$ ). The basal acidification responses were also significantly reduced $(P<0.05$, Wilcoxon Rank test $)$ in cells at $25^{\circ} \mathrm{C}$ compared to the responses in cells at $37^{\circ} \mathrm{C}\left(56 \pm 6\right.$ and $80 \pm 4 \mu \mathrm{V} \mathrm{s}^{-1}$, respectively, mean \pm s.e.mean, $n=7)$, and this effect was partially responsible for the increased response of the cells at $25^{\circ} \mathrm{C}$ when basal acidification responses were normalized and stimulated responses were expressed as a \% change from basal acidification responses $\left(16.2 \pm 1.5 \%\right.$ and $7.0 \pm 1.0 \%$ at $25^{\circ} \mathrm{C}$ and $37^{\circ} \mathrm{C}$, respectively, mean \pm s.e.mean, $n=7)$.

\section{The effect of $G A B A$ stimulation time on the acidification response}

GABA exposure times of $33 \mathrm{~s}$ and 6 min are shown in Figure 2. There is a transient spike pattern after a 33 s GABA stimulation, whereas longer stimulation times produce an initial transient spike followed by a sustained plateau phase until the GABA is removed. This decline in the GABA response after about 1 min $30 \mathrm{~s}$ of stimulation may represent a desensitization of the GABA-induced acidification rate, or possibly a secondary response. A $33 \mathrm{~s}$ GABA exposure time was used in all subsequent experiments to avoid possible complications of an attenuated GABA response.

The effect of a $12 \mathrm{~h}$ serum withdrawal on basal acidification responses and maximal GABA-mediated response

Serum deprivation of cerebellar granule cells at 7.5 DIV for $12 \mathrm{~h}$ before the measurement of acidification responses in the microphysiometer resulted in a low basal acidification rate $\left(35 \pm 12 \mu \mathrm{V} \mathrm{s}^{-1}\right.$, mean \pm s.e.mean, $\left.n=3\right)$, perhaps indicating dying or compromised cells. Alternatively, the effect could be

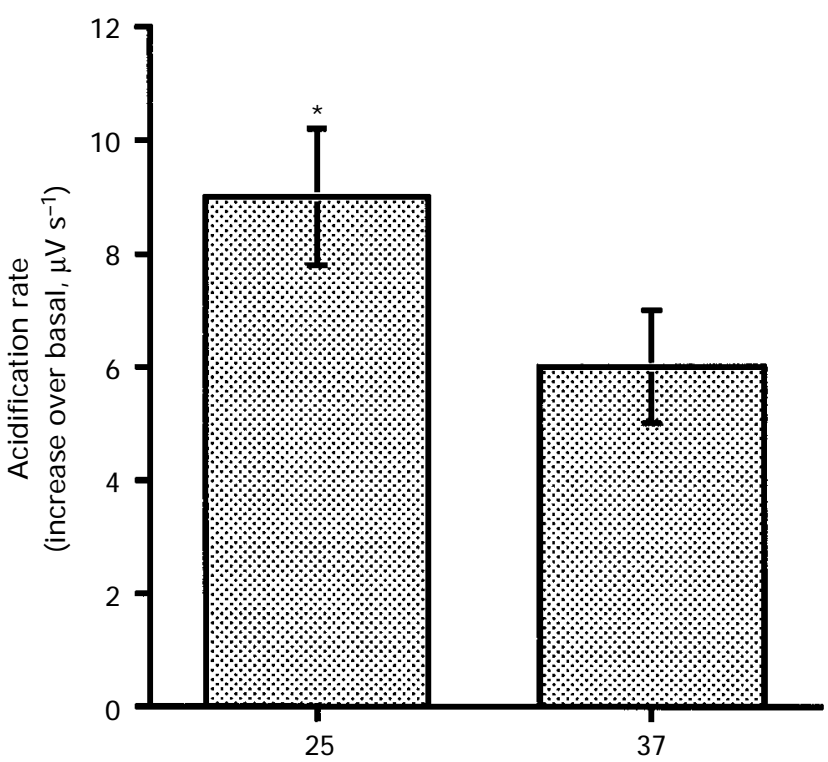

Incubation temperature $\left({ }^{\circ} \mathrm{C}\right)$

Figure 1 Effect of incubation temperature on GABA-mediated acidification rate in rat cerebellar granule cells. Rat CGC were prepared as described in Methods. At $8 \mathrm{DIV}$, cells were assessed for their extracellular acidification response to $100 \mu \mathrm{M}$ GABA (33 s stimulation) at 25 and $37^{\circ} \mathrm{C}$ by a microphysiometer. Responses are expressed as mean \pm s.e.mean increase in acidification rate over basal in $\mu \mathrm{V} \mathrm{s}^{-1}$ for 7 experiments from different cultures. Basal levels of acidification rate for cells at 25 and $37^{\circ} \mathrm{C}$ are $56 \pm 6$ and $80 \pm 4 \mu \mathrm{V}$ $\mathrm{s}^{-1}$, respectively. $* P<0.05$, significantly different from the response at $37^{\circ} \mathrm{C}$, Wilcoxon Rank test.

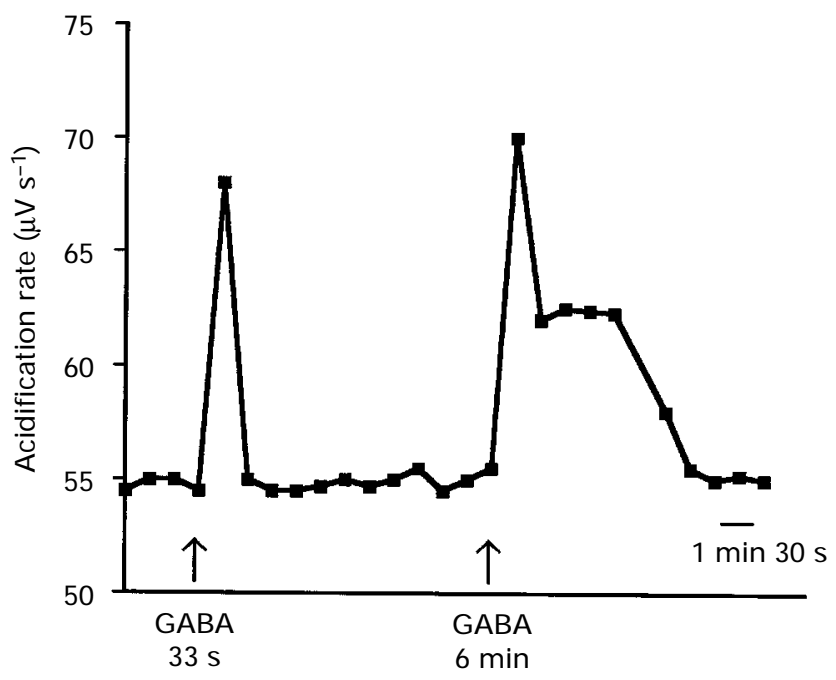

Figure 2 Acidification rate response in CGC at GABA exposure times of $33 \mathrm{~s}$ and $6 \mathrm{~min}$. Rat CGC were prepared as described in Methods. At 8 DIV, cells were assessed for their extracellular acidification response at $25^{\circ} \mathrm{C}$ to GABA $(100 \mu \mathrm{M})$ stimulation times of $33 \mathrm{~s}$ and $6 \mathrm{~min}$ by a microphysiometer. For the $33 \mathrm{~s}$ exposure, GABA was administered $50 \mathrm{~s}$ into the perfusion cycle $(1.5 \mathrm{~min})$, and for the 6 min exposure, GABA was applied at the beginning of the perfusion cycle. Measurements of acidification rate were taken during the period between $1 \mathrm{~min} 5 \mathrm{~s}$ and $1 \mathrm{~min} 28 \mathrm{~s}$ of the $1.5 \mathrm{~min}$ cycle ( $1 \mathrm{~min}$ perfusion, $30 \mathrm{~s}$ no perfusion). A washout with running medium for 6 min was performed between the two GABA exposures. Graph shows a representative experiment which was repeated on two further occasions with similar results. Extracellular acidification responses are given in $\mu \mathrm{V} \mathrm{s}^{-1}$. 
the result of lack of other activators of increased acidification rate which are present in the serum.

Following these initial optimization experiments, the conditions routinely employed to examine $\mathrm{GABA}_{\mathrm{A}}$ receptor acidification rate were: cells seeded at $9-12 \times 10^{5}$ cells/transwell cup, with experiments performed at a temperature of $25^{\circ} \mathrm{C}$, with no serum withdrawal before the experiments, and GABA stimulation time of $33 \mathrm{~s}$.

\section{GABA-mediated acidification responses and modulation by bicuculline and flunitrazepam}

Figure 3 shows the typical responses from two separate populations of cerebellar granule cells (8 DIV, originating from the same culture) to increasing concentrations of GABA $(10 \mathrm{nM}-1 \mathrm{mM})$. The basal acidification rate varied between populations of cells from the same cultures (Figure 3, typically ranging between 45 to $65 \mu \mathrm{V} \mathrm{s}^{-1}$ ). To allow the comparison of data within and between experiments, the GABA stimulated response data were normalized relative to the basal acidification rate. Expressing the data as an absolute increment over basal has been considered and found not to improve the variance of the data compared to $\%$ over basal. The representative cells shown in Figure 3 reveal that the absolute incremental response to the high concentrations of GABA (10, $100,1000 \mu \mathrm{M})$ are higher in the $60-62 \mu \mathrm{V} \mathrm{s}^{-1}$ basal level cells $\left(8.0,10.3,9.2 \mu \mathrm{V} \mathrm{s}^{-1}\right.$ over basal, respectively) than the $46-$ $47 \mu \mathrm{V} \mathrm{s}^{-1}$ basal level cells $\left(6.4,8.6,6.3 \mu \mathrm{V} \mathrm{s}^{-1}\right.$ over basal, respectively), but when expressed as \% over basal are essentially the same. This suggests that the GABA response is related to the initial basal value and may be the result of variations in the cell number on the transwell cups. In most of the experiments (e.g. Figure 3 ) at the lower concentrations of GABA $(<10 \mu \mathrm{M})$, possibly due to the small signals, this effect is more difficult to detect. Most previous studies have presumably come to the same conclusion that the basal levels affect the magnitude of the stimulated response and generally express the data as \% over basal (e.g. McConnell et al., 1992).
Figure 4 shows the cumulative GABA-induced concentrationresponse relationship which gives a best-fit $\mathrm{GABA} \mathrm{EC}_{50}$ value of $2.0 \pm 0.2 \mu \mathrm{M}$ (mean \pm s.e.mean, $n=7$ experiments), $\mathrm{E}_{\max }$ of $15.4 \pm 1.2 \%$ over basal and a Hill slope value of 0.8 . Figure 5 demonstrates that the GABA-induced acidification rate can be significantly potentiated $(P<0.05)$ at low GABA concentrations $(10 \mathrm{nM}-1 \mu \mathrm{M}$ GABA) by $100 \mathrm{nM}$ flunitrazepam (maximal potentiation occurs at $10 \mathrm{nM}$ GABA, the mean increment of $1.4 \mu \mathrm{V} \mathrm{s}^{-1}$ over basal is potentiated by $271 \%$ in the presence of flunitrazepam to $3.8 \mu \mathrm{V} \mathrm{s}^{-1}$ over basal, $n=7$ ) and inhibited by bicuculline $(100 \mu \mathrm{M})$ administered $30 \mathrm{~min}$ before and during the GABA stimulation period. Flunitrazepam (100 nM) or bicuculline $(100 \mu \mathrm{M})$ in the absence of GABA do not significantly affect the extracellular acidification rate (flunitrazepam: $1.3 \pm 0.6 \%$, bicuculline: $4.0 \pm 2.5 \%$ increase over basal (vehicle $0.1 \% \mathrm{v} / \mathrm{v}$ ethanol) levels, mean \pm s.e.mean, $n=3$ ).

\section{Discussion}

The results presented here show that GABA, acting via the $\mathrm{GABA}_{\mathrm{A}}$ receptor, can increase the extracellular acidification rate in primary cultures of rat cerebellar granule cells, and demonstrate the feasibility of using microphysiometry for measuring $\mathrm{GABA}_{\mathrm{A}}$ receptor function. The sub-maximal GABA-induced increase in acidification rate can be potentiated by the 1,4-benzodiazepine flunitrazepam and inhibited by the competitive $\mathrm{GABA}_{\mathrm{A}}$ receptor antagonist bicuculline.

The conditions that produce the most reliable and consistent response to GABA are shown to be cells seeded between 9 and $12 \times 10^{5}$ cells per transwell cup, at $25^{\circ} \mathrm{C}$, with response data expressed as $\%$ of basal acidification rate. The GABA response obtained in rat cerebellar granule cells by use of the microphysiometer demonstrates typical $\mathrm{GABA}_{\mathrm{A}}$ receptormediated characteristics (Sieghart, 1985). The response to GABA was concentration-dependent with a best-fit $\mathrm{EC}_{50}$ of $2.0 \mu \mathrm{M}$, very similar to that previously obtained from electro-

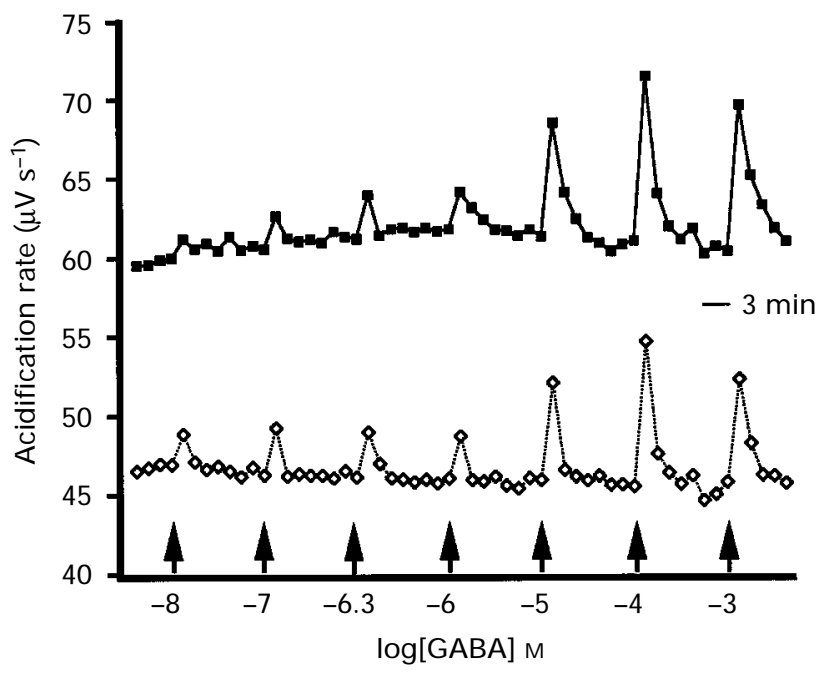

Figure 3 Acidification rate response to increasing GABA concentrations in two populations of rat cerebellar granule cells. Rat CGC were prepared as described in Methods. At 8 DIV, cells were assessed for their extracellular acidification response to increasing concentrations of GABA $\left(10 \mathrm{~nm}-1 \mathrm{~mm}, 33 \mathrm{~s}\right.$ stimulation, $25^{\circ} \mathrm{C}$ application indicated by arrows) by a microphysiometer. A washout period of 15 min with running medium occurred between each GABA concentration. $(\square)$ and $(\diamond)$ Typical concentration-response relationships from 2 populations of cells derived from the same culture to show the GABA responses at the extremes of the range of basal acidification responses (mean basal acidification rate was $56 \pm 6 \mu \mathrm{V}$ $\left.\mathrm{s}^{-1}, n=7\right)$. Extracellular acidification rate responses are given in $\mu \mathrm{V}$ $\mathrm{s}^{-1}$.

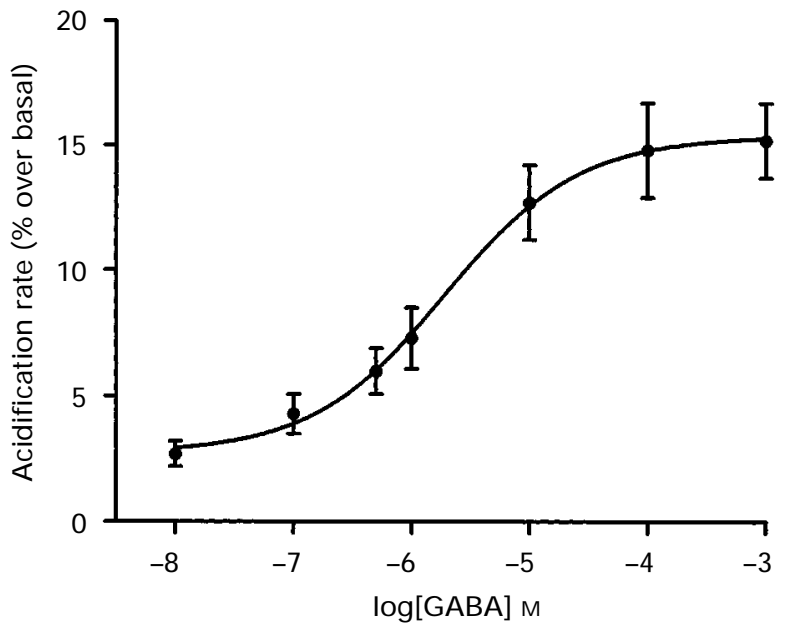

Figure 4 Cumulative GABA concentration-response relationship. Cerebellar granule cells were prepared as described in Methods. At 8 DIV, cells were assessed for their extracellular acidification response to increasing concentrations of GABA $(10 \mathrm{~nm}-1 \mathrm{~mm}, 33 \mathrm{~s}$ exposure) by a microphysiometer. A washout period of $15 \mathrm{~min}$ with running medium occurred between each GABA concentration. Results are expressed as mean \% change over basal acidification rate for 7 experiments from different cultures performed in duplicate; vertical lines show s.e.mean. The graph shows the bestfit line with an $\mathrm{EC}_{50}$ for GABA of $2.0 \pm 0.2 \mu \mathrm{M}$, an $\mathrm{E}_{\max }$ of $15.4 \pm 1.2 \%$ and a Hill slope of 0.8 . Curve fitting was performed by the sigmoidal concentration-response equation (variable slope) implemented with Prism software. 


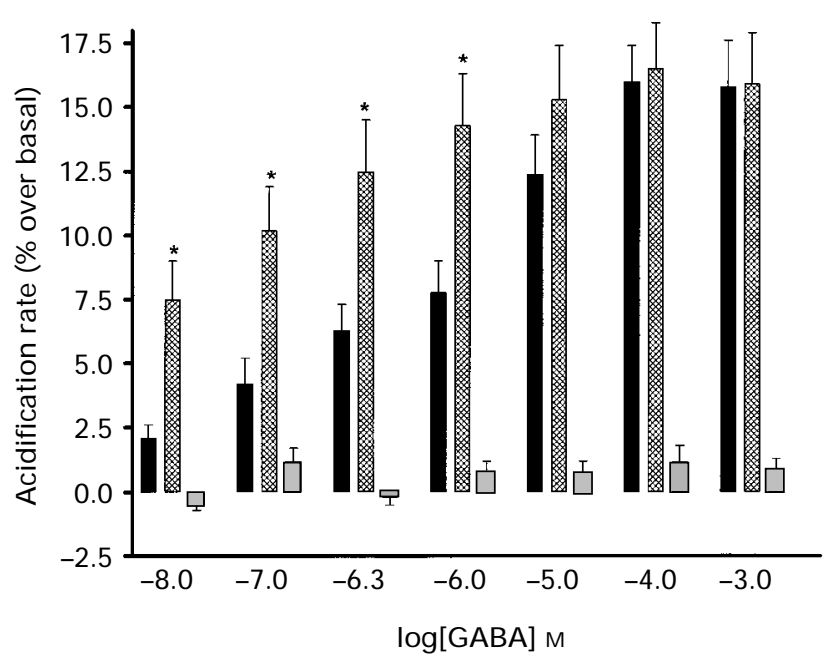

Figure 5 Modulation of GABA-mediated extracellular acidification rate in rat $\mathrm{CGC}$ by flunitrazepam and bicuculline. Rat CGC were prepared as described in Methods. At 8 DIV, cells were examined for their extracellular acidification response to increasing concentrations of GABA $(10 \mathrm{nM}-1 \mathrm{~mm}, 33 \mathrm{~s}$ exposure) and vehicle $(0.1 \%(\mathrm{v} / \mathrm{v})$ ethanol) with a washout period of 15 min with running medium between each GABA concentration. A washout period of $30 \mathrm{~min}$ with running medium removed the GABA, and cells were then exposed for $30 \mathrm{~min}$ to flunitrazepam $(100 \mathrm{nM})$ or bicuculline $(100 \mu \mathrm{M})$. Responses to increasing concentrations of GABA were repeated in the presence of $100 \mathrm{~nm}$ flunitrazepam (cross-hatched columns) or $100 \mu \mathrm{M}$ bicuculline (stippled columns) with washout periods of $15 \mathrm{~min}$ with running medium (containing bicuculline or flunitrazepam, as appropriate) occurring between each GABA concentration. Solid columns show control responses to GABA+ vehicle. Results are expressed as mean \% over basal acidification rate \pm s.e.mean $\%$ for between 3 and 7 experiments from different cultures performed in duplicate. *Significantly different $(P<0.05)$ from GABA response by the Wilcoxon Rank test.

physiological studies in cerebellar granule cells; $1.6 \mu \mathrm{M}$ at 5 DIV (Zheng et al., 1994) and $2.3 \mu \mathrm{M}$ at 5-12 DIV (Robello et al., 1993). The GABA response declines at $>1 \mathrm{~min} 30 \mathrm{~s}$ of GABA $(100 \mu \mathrm{M})$ stimulation, which may represent a desensitization of the response since it is consistent with previous studies of $\mathrm{GABA}_{\mathrm{A}}$ receptor desensitization (Cash \& Subbaro, 1987). The pharmacology of the response is typical of the $\mathrm{GABA}_{\mathrm{A}}$ receptor subtype (Macdonald \& Olsen, 1994); it can be blocked by bicuculline $(100 \mu \mathrm{M})$ and potentiated by the $1,4-$ benzodiazepine, flunitrazepam $(100 \mathrm{nM})$. The potentiation of the GABA response by flunitrazepam is restricted to submaximal GABA concentrations, as has been shown previously (Lehoullier \& Ticku, 1987).

\section{References}

BORMANN, J., HAMILL, O.P. \& SAKMANN, B. (1987). Mechanism of anion permeation through channels gated by glycine and gamma aminobutyric acid in mouse cultured spinal neurons. J. Physiol., 385, $243-286$.

BROWN, M.J. \& BRISTOW, D.R. (1996). Molecular mechanisms of benzodiazepine-induced down-regulation of $\mathrm{GABA}_{\mathrm{A}}$ receptor $\alpha_{1}$ subunit protein in rat cerebellar granule cells. Br. J. Pharmacol., $\mathbf{1 1 8}, 1103-1110$.

CAO, V., OWICKI, J.C., EDGAR, D. \& MILLER, J.D. (1991). Effect of cholinergic agents on cellular metabolism in cultured suprachiasmatic nucleus. Soc. Neurosci. Abstr., 17, 672.

CASH, D.J. \& SUBBARAO, K. (1987). Desensitization of gammaaminobutyric acid receptor from rat brain: two distinguishable receptors on the same membrane. Biochemistry, 26, 7556-7562.
The GABA-induced response in cerebellar granule cells is small (approx. 14-16\% increase over basal acidification rate) in comparison to the responses generated by activation of Gprotein coupled (carbachol stimulates about $20 \%$ increase over basal acidification rate) and tyrosine kinase-linked receptors (nerve growth factor stimulates about 30\% increase over basal acidification rate, McConnell et al., 1992). With insufficient examples of ligand-gated ion channel responses with this system (e.g. Raley-Susman et al., 1992), it is not possible to say whether this small effect on extracellular acidification rate is a characteristic of ligand-gated ion channel receptors in general, or a feature of the $\mathrm{GABA}_{\mathrm{A}}$ receptor-induced response in cerebellar granule cells. It is also worth noting that the G-proteinand tyrosine kinase-receptor responses were measured in transfected cell lines which may give abnormally high extracellular acidification rates and receptor densities in comparison to primary cultured neurones.

These studies show the feasibility of employing the technique of microphysiometry in the study of $\mathrm{GABA}_{\mathrm{A}}$ receptor function in populations of neurones. The procedure is consistent and sensitive and provides an alternative technique to ${ }^{36}$ chloride flux, which is the usual method to measure $\mathrm{GABA}_{\mathrm{A}}$ receptor function in populations of neurones (Thampy \& Barnes, 1984; Lehoullier \& Ticku, 1987; Marley \& Gallager, 1989; Miller et al., 1988; Hu \& Ticku, 1994). There are several possible advantages of microphysiometry over the ${ }^{36}$ chloride flux technique to study $\mathrm{GABA}_{\mathrm{A}}$ receptor function. For example, the potential of using extended treatment times, during which the cells can be continuously perfused to maintain viability, the rapid and 'real-time' acquisition of data, and the ability to measure multiple concentrations and drug effects on the same population of cells, due to the ability to washout the compounds.

This study is the first to demonstrate a $\mathrm{GABA}_{\mathrm{A}}$ receptormediated increase in extracellular acidification rate in primary cultured CNS neuronal cells with a microphysiometer. The technique detected the classical pharmacological profile of the $\mathrm{GABA}_{\mathrm{A}}$ receptors; the inhibition by bicuculline and potentiation of the response by benzodiazepines. The microphysiometer provides a rapid and sensitive technique to investigate the regulation of the $\mathrm{GABA}_{\mathrm{A}}$ receptor in populations of neurones.

The authors would like to express their thanks to the Medical Research Council (G9213132N) for financial support, and to the BBSRC for their studentship to M.J.B. The authors would also like to thank Jon Waterman-Smith from Molecular Devices Ltd., for his advice and support which enabled this work to continue on the microphysiometer in Manchester.
HU, X.J. \& TICKU, M.K. (1994). Chronic flurazepam treatment produces decreased efficacy of the benzodiazepine ligands and pentobarbital with $\gamma$-aminobutyric acid $_{\mathrm{A}}$ receptors in cortical neurons. J. Pharmacol. Exp. Ther., 270, 485-490.

LEHOUlLIER, P.F. \& TICKU, M.K. (1987). Benzodiazepine and $\beta$ carboline modulation of GABA-stimulated ${ }^{36} \mathrm{Cl}$-influx in cultured spinal neurons. Eur. J. Pharmacol., 135, 235-238.

MACDONALD, R.L. \& OLSEN, R.W. (1994). GABA Geceptor channels. Ann. Rev. Neurosci., 17, 569-602.

MARLEY, R.J. \& GALlAGER, D.W. (1989). Chronic diazepam treatment produces regionally specific changes in GABAstimulated chloride influx. Eur. J. Pharmacol., 159, 217-223. 
MCCONNELL, H.M., OWICKI, J.C., PARCE, J.W., MILlER, D.L., BAXTER, G.T., WADA, H.G. \& PRITCHFORD, S. (1992). The Cytosensor microphysiometer: biological applications of silicon technology. Science, 257, 1096-1912.

MILLER, L.G., GREENBLAT, D.J., BARNHILL, J.G. \& SHADER, R.I. (1988). Chronic benzodiazepine administration I. Tolerance is associated with benzodiazepine receptor down-regulation and

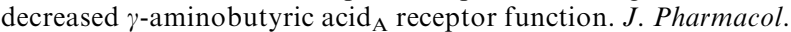
Exp. Ther., 246, $170-176$.

NAG, K.A., ROSSER, M.P. \& BARBER, D.L. (1995). Regulation of $\mathrm{Na}^{+}-\mathrm{H}^{+}$exchange of $\mathrm{G}$-protein coupled receptors. Methods Neurosci., 25, 225-241.

NAG, B., WADA, H.G., FOK, K.S., GREEN, D.J., SHARMA, S.D., CLARK, B.R., PARCE, J.W. \& MCCONNELL, H.M. (1992). Antigenspecific stimulation of T Cell: Extracellular acidification by MHC class II-peptide complexes. J. Immunol., 148, 2040 - 2044.

NAYEEM, N., GREEN, T.P., MARTIN, I.L. \& BARNARD, E.A. (1994) Quaternary structure of the native GABA(A) receptor determined by electron microscopic image analysis. J. Neurochem., 62 , $815-818$.

OWICKI, J.C., PARCE, J.W., KERSCO, K.M., SIGAL, G.B., MUIR, V.C., VENTER, J.C., FRASER, C.M. \& MCCONNELL, H.M. (1990). Continuous monitoring of receptor-mediated changes in metabolic rates in living cells. Proc. Natl. Acad. Sci. U.S.A., 87, $4007-$ 4011.

PARCE, J.W., OWICKI, J.C., KERSCO, K.M., SIGAL, G.B., WADA, H.G., MUIR, V.C., BOUSSE, L.J., ROSS, K L \& MCCONNELL, H.M. (1989). Detection of cell-affecting agents with a silicon biosensor. Science, 246, $243-247$.

RALEY-SUSMAN, K.M., KERSCO, K.M., PARCE, J.W., OWICKI, J.C. \& SAPOLSKY, R.M. (1990). Direct measurement of neurotransmitter activation of cellular metabolism in cultured hippocampal neurons. J. Cell. Biol., 111, 339a.
RALEY-SUSMAN, K.M., MILLER, K.R., OWICKI, J.C. \& SAPOLSKY, R.M. (1992). Effects of excitotoxin exposure on metabolic rate of primary hippocampal cultures: Application of silicon microphysiometry to neurobiology. J. Neurosci., 12, 773-780.

RICE, P A. OWICKI, J.C., PARCE, J.W. \& MCCONNELL, H.M. (1991). Transient cellular responses detected in a microphysiometer. FASEB J., 5, A1014.

ROBEllo, M., AMICO, C. \& CUPELlO, A. (1993). Regulation of $\mathrm{GABA}_{\mathrm{A}}$ receptor in cerebellar granule cells in culture: differential involvement of kinase activities. Neuroscience, 53, 131-138.

SALON, J.A. \& OWICKI, J.C. (1995). Real-time measurement of receptor activity: Applications of microphysiometry techniques to receptor biology. Methods Neurosci., 25, 201-224.

SIEGHART, W. (1995). Structure and pharmacology of $\gamma$-aminobu-

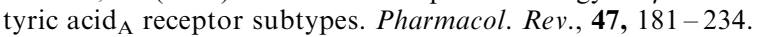

THAMPY, K.G. \& BARNES, E.M.J. (1984). $\gamma$-Aminoburytic acid-gated chloride channels in cultured cerebral neurons. J. Biol. Chem., 259, $1753-1757$.

WADA, H.G., INDELICATA, R., MEYER, L., KITAMUTA, T. MIYAJIMA, A., KIRK, G., MUIR, V.C. \& PARCE, J.W. (1993). GM-CSF triggers a rapid, glucose-dependent extracellular acidification by TP-1 cells: Evidence for sodium/proton antiporter and PKC mediated activation of acid production. J. Cell Physiol., 154, 129-138.

ZHENG, T.M., ZHU, W.J., PUIA, G., VICINI, S., GRAYSON, D.R., COSTA, E. \& CARUNCHO, H.J. (1994). Changes in gammaaminobutyrate type A receptor subunit mRNAs, translation product expression, and receptor function during neuronal maturation in vitro. Proc. Natl. Acad. Sci. U.S.A., 91, $10952-$ 10956.

Received November 14, 1996 Revised January 16, 1997 Accepted January 29, 1997) 